\title{
Detection of rifampin-resistant genotypes in Mycobacterium tuberculosis by reverse hybridization assay
}

\author{
Raquel de A Maschmann ${ }^{1,2} /{ }^{+}$, Mirela Verza ${ }^{1,2}$, Marcia SN Silva ${ }^{1,3}$, Rosa Dea Sperhacke ${ }^{4}$, \\ Marta O Ribeiro', Philip Noel Suffys ${ }^{5}$, Harrison Magdinier Gomes ${ }^{5}$, Enrico Tortoli ${ }^{6}$, \\ Fiorella Marcelli ${ }^{6}$, Arnaldo Zaha ${ }^{2}$, Maria Lucia R Rossetti ${ }^{1,2,3}$
}

${ }^{1}$ Fundação Estadual de Produção e Pesquisa em Saúde, Porto Alegre, RS, Brasil ²Programa de Pós-Graduação em Biologia Celular e Molecular, Centro de Biotecnologia, Universidade Federal do Rio Grande do Sul, Porto Alegre, RS, Brasil ${ }^{3}$ Universidade Luterana do Brasil, Canoas, RS, Brasil ${ }^{4}$ Laboratório de Pesquisa em HIV/AIDS, Universidade de Caxias do Sul, Caxias do Sul, RS, Brasil ${ }^{5}$ Instituto Oswaldo

Cruz-Fiocruz, Rio de Janeiro, RJ, Brasil ${ }^{6}$ Centro Regionale di Riferimento per i Micobatteri, Ospedale di Careggi, Firenze, Italy

We used a colorimetric reverse dot blot hybridization (CRDH) assay to detect the presence of mutations in a specific region of the $\mathrm{rpo} B$ gene, associated with rifampin (RIF) resistance, in a panel of 156 DNAs extracted from 103 RIF-sensitive and 53 RIF-resistant cultures of Mycobacterium tuberculosis. When compared with the antimicrobial susceptibility test (AST), the sensitivity and specificity of the CRDH were $92.3 \%$ and $98.1 \%$, respectively. When compared with sequencing, the sensitivity and specificity of the CRDH were $90.6 \%$ and $100 \%$, respectively. To evaluate the performance of the assay directly in clinical specimens, 30 samples from tuberculosis patients were used. For these samples, the results of the CRDH were $100 \%$ consistent with the results of the AST and sequencing. These results indicate that the rate of concordance of the CRDH is high when compared to conventional methods and sequencing data. The CRDH can be successfully applied when a rapid test is required for the identification of $R I F$ resistance in $\mathrm{M}$. tuberculosis.

Key words: drug resistance - reverse dot blot hybridization - rifampin - rpoB - tuberculosis

Tuberculosis (TB) is a global health problem and approximately 1.5 million people die from TB every year. Brazil is one of the 22 countries responsible for $80 \%$ of the total global TB incidence. The estimated TB incidence in Brazil is 48 out of 100,000 inhabitants (WHO 2009).

A new and potentially devastating threat to TB control is the emergence of strains that cannot be cured by standard anti-TB drug regimens (Lawn \& Wilkinson 2006). Drug resistant TB commonly arises through the selection of mutated strains by inadequate chemotherapy. Resistance to at least two major anti-TB drugs, rifampin (RIF) and isoniazid (INH) has been termed multidrugresistant TB (MDR-TB). Treatment of MDR-TB requires prolonged and expensive chemotherapy using second-line drugs. These problems compromised the progress made in TB control during the past decade (WHO 2009).

Resistance to RIF is an excellent marker for MDRTB, as $90 \%$ of RIF-resistant Mycobacterium tuberculosis strains are also INH resistant (Telenti et al. 1993, Cole \& Telenti 1995, Ramaswamy \& Musser 1998). Molecular tests for the detection of RIF resistance has also been developed because almost all RIF resistant $M$. tuberculosis strain mutations are found in the short hot-

Financial support: CNPq, FINEP, FEPPS

+ Corresponding author: raquel368@gmail.com

Received 27 July 2010

Accepted 24 November 2010 spot region (81-bp) of the rpoB gene (Kapur et al. 1994, Telenti et al. 1997, Valim et al. 2000), which encodes the $\beta$-subunit of the RNA polymerase (Telenti et al. 1993, Heep et al. 2001). In isolates from Brazil (Valim et al. 2000) and other countries (Hillemann et al. 2005, Miotto et al. 2006), the most frequently affected codons by point mutations are 531, 526 and 516.

An accurate and early detection of drug resistance in clinical M. tuberculosis isolates is crucial for the appropriate treatment and to prevent the development of further resistance and the spread of resistant strains. Drug susceptibility testing by conventional methods takes more than four weeks. Generally, DNA sequencingbased approaches are considered the reference assays for the detection of mutations, but often they have been found to be too cumbersome for routine use. The commercial molecular hybridization tests, such as GenoType MTBDR (Hain Lifescience, Nehren, Germany) and INNO-LiPA Rif.TB (Innogenetics, Zwijndrcht, Belgium) are sensitive and specific, but the high cost and the need for validation hamper the widespread application of the test-kits in geographic areas where it is most urgently needed (Mäkinen et al. 2006).

In this study, we tested a molecular assay for the detection of M. tuberculosis RIF resistance based on colorimetric reverse dot blot hybridization (CRDH). Previously, a similar strategy was developed by Verza et al. (2009) in our laboratory. The results from the CRDH were compared with the data obtained by DNA sequencing and antimicrobial susceptibility test (AST) and some DNAs were also analyzed by the GenoType MTBDR commercial test. 


\section{MATERIALS AND METHODS}

Strains and clinical isolates - To standardize and evaluate the CRDH, we used a panel of 156 DNAs obtained from M. tuberculosis cultures that had been submitted to both AST and partial rpoB gene sequencing. This panel contained 103 DNA samples with no mutations and 53 DNA samples with one or more mutations in the hot-spot region of the rpoB and associated with RIF-resistance in this region (Table I). The strains were selected from the collection of the Institute of Biological Research/Central Laboratory of Rio Grande do Sul, Brazil (IPB/LACEN-RS). The M. tuberculosis H37Rv (ATCC 27294) reference strain was used as a wild-type (WT) control. The specimens had previously been cultured on Ogawa medium and identified as M. tuberculosis based on a positive niacin test. AST was performed using Lowenstein-Jensen medium according to the proportion method (Canetti et al. 1963).

After standardization with DNA extracted from the cultures, the CRDH method was performed on DNA extracted from 30 clinical isolates from the IPB/LACENRS, Brazil, and the Laboratorio di Microbiologia e Virologia of the Centro Regionale di Riferimento per $\mathrm{i}$ Micobatteri, Ospedale di Careggi, Florence, Italy. These samples were examined microscopically for the presence of acid-fast bacilli and then submitted to AST and partial rpoB gene sequencing.

DNA extraction - Nucleic acids were extracted from M. tuberculosis cultures using the CTAB method as described by van Soolingen et al. (1994). Nucleic acids of M. tuberculosis from the clinical samples were extracted using the method adapted from Boom et al. (1990). All respiratory specimens had been decontaminated previously by the $\mathrm{N}$-acetyl-L-cysteine- $\mathrm{NaOH}$ conventional method (Kent \& Kubica 1985).

Polymerase chain reaction (PCR) amplification For development of the CRDH, a 157-bp fragment of the $r p o \mathrm{~B}$ gene was amplified using the primers RF1 (5'-GGTCGCCGCGATCAAGGAGT-3') and RF2 (5'TGCACGTCGCGGACCTCCA-3') and a 245-bp fragment of the insertion element sequence IS6110 (TB control) using the primers INS1 and INS2 as described by Hermans et al. (1990). The reverse primers were biotinlabelled and the PCR-duplex was standardized in a final volume of $50 \mu \mathrm{L}$ containing $200 \mu \mathrm{M}$ of each dNTP, $10 \mathrm{mM}$ Tris-HCL (pH 8), $50 \mathrm{mM} \mathrm{KCL}, 2 \mathrm{mM} \mathrm{MgCl}$, 10 pmoles of each primer (RF1/RF2 and INS1/INS2), 50-100 ng of purified DNA and 2.5 U of Taq DNA polymerase (Cebiot, UFRGS, Brazil). The PCR reactions were carried out as follows: $3 \mathrm{~min}$ at $95^{\circ} \mathrm{C}, 30$ cycles of $1 \mathrm{~min}$ at $95^{\circ} \mathrm{C}, 1 \mathrm{~min}$ at $60^{\circ} \mathrm{C}, 1.5 \mathrm{~min}$ at $72^{\circ} \mathrm{C}$, and $4 \mathrm{~min}$ at $72^{\circ} \mathrm{C}$. For amplification of the clinical samples, $10 \mu \mathrm{L}$ of the processed material was submitted to the same conditions as above for 40 thermal cycles. The PCR products were analyzed by electrophoresis in a $1.5 \%$ agarose gel.

$D N A$ sequencing of the rpoB gene - For sequencing, a 157-bp fragment of the $r p o \mathrm{~B}$ gene was amplified with the primers, RF1 and RF2, as described above. Amplifications were carried out as follows: 30 cycles at $94^{\circ} \mathrm{C}$ for $2 \mathrm{~min}, 65^{\circ} \mathrm{C}$ for $1 \mathrm{~min}$ and $72^{\circ} \mathrm{C}$ for $2 \mathrm{~min}$. The PCR products were purified using the polyethylene glycol method, listed on the Multilocus Sequence Typing website (http://pubmlst.org/neisseria/mlst-info/ nmeningitidis/pcr.shtml) and sequenced using Big Dye ${ }^{\circledR}$ Terminator Cycle Sequencing Kit with AmpliTaq DNA polymerase (Applied Biosystems, Foster City, CA, USA) in the ABI Prism 3100 DNA Sequencer (Applied Biosystems). The sequences were analyzed using programs PREGAP and GAP4 from STADEN package 10.0. Nucleotide sequences with phred values $>20$ were considered for analysis.

GenoType MTBDR assay - The CRDH results of 15 out of 156 DNAs were compared with the results of GenoType MTBDR, a molecular test used for the determination of mutations associated with susceptibility to RIF and INH. The assay was performed according to the manufacturer's instructions.

CRDH test - A total of 10 oligonucleotide probes were designed to screen the most frequent WTand mutant genotypes of the rpoB gene using the Primer Express Software v2.0 (Applied Biosystems). Additionally, one oligonucleotide probe specific to M. tuberculosis complex (MTBC), complementary to an internal sequence of the insertion element IS6110, was constructed. All oligonucleotide probes (Invitrogen) were designed with a 5'-terminal amino group. The oligonucleotide sequences are listed in Table II. The negatively-charged nylon membrane (Biodyne C, Pall Corporation) was activated in a solution of $16 \%$ (w/v) EDAC [1-(3dimethylaminopropyl)-3-ethylcarbodiimide hydrochloride, Acros Organics] for $15 \mathrm{~min}$ at room temperature (RT) and washed in distilled water for $2 \mathrm{~min}$ at RT. Then $10 \mu \mathrm{L}$ each of oligonucleotide probe, diluted to the appropriate concentration (Table II) in $0.5 \mathrm{M} \mathrm{NaHCO}_{3}$ ( $\mathrm{pH} 8.4)$ and the conjugate control (CC) $(0.01 \mu \mathrm{g} / \mu \mathrm{L}$ of streptavidin-alkaline phosphatase conjugate, Invitrogen) were spotted separately in 12 circles and incubated for $1 \mathrm{~min}$ at RT. Membranes were incubated in $0.1 \mathrm{M} \mathrm{NaOH}$ for $10 \mathrm{~min}$, washed in distilled water for $2 \mathrm{~min}$ at RT, washed in $2 \mathrm{x} \mathrm{SSC} / 0.1 \% \mathrm{SDS}$ for $10 \mathrm{~min}$ at $50^{\circ} \mathrm{C}$ and finally incubated in $20 \mathrm{mM}$ EDTA $(\mathrm{pH} 8)$ for $15 \mathrm{~min}$ at RT. The membranes were then transferred into a polyethylene tube and stored at $4^{\circ} \mathrm{C}$ for posterior use.

The membranes were washed in $2 x \mathrm{SSC} / 0.1 \%$ SDS for $5 \mathrm{~min}$ at $50^{\circ} \mathrm{C}$ and incubated in $2 \mathrm{x}$ SSC with $3 \%$ bovine serum albumin (BSA) (INLAB) at $50^{\circ} \mathrm{C}$ for $15 \mathrm{~min}$. Twenty microliters of each PCR reaction was added to $150 \mu \mathrm{L} 2 \mathrm{x} \mathrm{SSC} / 0.1 \% \mathrm{SDS}$, denatured at $100^{\circ} \mathrm{C}$ for $10 \mathrm{~min}$ and transferred to an ice bath. The denatured PCR product was then added into polyethylene tube containing a membrane in $1 \mathrm{~mL}$ of hybridization solution (2x SSC $/ 0.1 \%$ SDS). The hybridization was achieved by incubating at $62^{\circ} \mathrm{C}$ for $45 \mathrm{~min}$. After hybridization, the membranes were washed in $2 x \mathrm{SSC} / 0.5 \%$ SDS and in $0.2 \times \mathrm{SSC} / 0.5 \% \mathrm{SDS}$ at $57^{\circ} \mathrm{C}$ for $10 \mathrm{~min}$ each. The membranes were then treated with a Tris-buffered saline (TSB) (100 mM Tris- $\mathrm{HCl}, 150 \mathrm{mM} \mathrm{NaCl}, \mathrm{pH} 7.5)$ containing $6 \% \mathrm{BSA}$ for $30 \mathrm{~min}$ at $50^{\circ} \mathrm{C}$, followed by a second incubation in TSB for $5 \mathrm{~min}$ at RT. The mem- 
TABLE I

Correlation between colorimetric reverse dot blot hybridization (CRDH), sequencing and antimicrobial susceptibility test (AST)

\begin{tabular}{|c|c|c|c|c|c|c|c|}
\hline \multicolumn{2}{|c|}{ CRDH pattern } & \multirow[b]{2}{*}{$\begin{array}{c}\text { CRDH result } \\
\text { (location of } r p o \mathrm{~B} \text { mutation) }\end{array}$} & \multicolumn{2}{|c|}{ Sequencing data } & \multirow[b]{2}{*}{$\begin{array}{l}\text { Strains } \\
(\mathrm{n}=156)\end{array}$} & \multicolumn{2}{|c|}{ AST to RIF } \\
\hline $\begin{array}{l}\text { Positive with } \\
\text { wild type probes }\end{array}$ & $\begin{array}{l}\text { Positive with } \\
\text { mutant probes }\end{array}$ & & $\begin{array}{c}\text { Affected } \\
\text { codon }(\mathrm{s}) \\
\text { in rpoB gene }\end{array}$ & $\begin{array}{c}\text { Nucleotide/amino acid } \\
\text { change(s) }\end{array}$ & & $\begin{array}{c}\mathrm{R} \\
(\mathrm{n}=52)\end{array}$ & $\begin{array}{c}S \\
(n=104)\end{array}$ \\
\hline $1,2,3,4$ & Mut S531L & S531L & 531 & $\mathrm{TCG} \rightarrow \mathrm{TTG} / \mathrm{Ser} \rightarrow \mathrm{Leu}$ & 18 & 17 & 1 \\
\hline $1,2,3,5$ & Mut H526Y & H526Y & 526 & $\mathrm{CAC} \rightarrow \mathrm{TAC} / \mathrm{His} \rightarrow \mathrm{Tyr}$ & 3 & 3 & - \\
\hline $1,2,3,5$ & & $525-529$ & 526 & $\mathrm{CAC} \rightarrow \mathrm{CGC} / \mathrm{His} \rightarrow \mathrm{Arg}$ & 3 & 3 & - \\
\hline $1,2,3,5$ & Mut H526D & H526D & 526 & $\mathrm{CAC} \rightarrow \mathrm{GAC} / \mathrm{His} \rightarrow \mathrm{Asp}$ & 2 & 2 & - \\
\hline $1,2,3,5$ & & $525-529$ & 526 & $\mathrm{CAC} \rightarrow \mathrm{CTC} / \mathrm{His} \rightarrow \mathrm{Leu}$ & 1 & 1 & - \\
\hline $1,2,3,5$ & & $525-529$ & 526 & $\mathrm{CAC} \rightarrow \mathrm{TGC} / \mathrm{His} \rightarrow \mathrm{Cys}$ & 2 & 1 & 1 \\
\hline $1,2,4,5$ & & $519-525$ & 522 & $\mathrm{TCG} \rightarrow \mathrm{TTG} / \mathrm{Ser} \rightarrow \mathrm{Leu}$ & 1 & 1 & - \\
\hline $1,3,4,5$ & Mut D516V & D516V & 516 & $\mathrm{GAC} \rightarrow \mathrm{GTC} / \mathrm{Asp} \rightarrow \mathrm{Val}$ & 6 & 6 & - \\
\hline $1,3,4,5$ & & $514-520$ & 516 & $\mathrm{GAC} \rightarrow \mathrm{TAC} / \mathrm{Asp} \rightarrow \mathrm{Tyr}$ & 1 & 1 & - \\
\hline $1,2^{a}, 3,4,5$ & & rpoB WT & 516 & $\mathrm{GAC} \rightarrow \mathrm{TAC} / \mathrm{Asp} \rightarrow \mathrm{Tyr}$ & 1 & 1 & - \\
\hline $1^{a}, 2,3,4,5$ & & rpoB WT & 513 & $\mathrm{CAA} \rightarrow \mathrm{CCA} / \mathrm{Gln} \rightarrow$ Pro & 1 & 1 & - \\
\hline $2,3,4,5$ & & $509-514$ & 511 & $\mathrm{CTG} \rightarrow \mathrm{CCG} / \mathrm{Leu} \rightarrow$ Pro & 1 & 1 & - \\
\hline $1,3,5$ & & $\begin{array}{l}514-520 \\
525-529\end{array}$ & $\begin{array}{l}516 \\
526\end{array}$ & $\begin{array}{l}\mathrm{GAC} \rightarrow \mathrm{GGC} / \mathrm{Asp} \rightarrow \text { Gly } \\
\mathrm{CAC} \rightarrow \mathrm{AAC} / \mathrm{His} \rightarrow \mathrm{Asn}\end{array}$ & 1 & 1 & - \\
\hline $2,3,4$ & Mut S531L & $\begin{array}{l}509-514 \\
\text { S531L }\end{array}$ & $\begin{array}{l}514 \\
531\end{array}$ & $\begin{array}{l}\mathrm{TTC} \rightarrow \mathrm{GTC} / \mathrm{Phe} \rightarrow \text { Val } \\
\mathrm{TCG} \rightarrow \mathrm{TTG} / \mathrm{Ser} \rightarrow \text { Leu }\end{array}$ & 1 & 1 & - \\
\hline $3,4,5$ & & $\begin{array}{l}509-514 \\
514-520\end{array}$ & $\begin{array}{l}511 \\
515\end{array}$ & $\begin{array}{c}\mathrm{CTG} \rightarrow \mathrm{CCG} / \mathrm{Leu} \rightarrow \text { Pro } \\
\mathrm{ATG} \rightarrow \mathrm{ATA} / \mathrm{Met} \rightarrow \mathrm{Ile}\end{array}$ & 1 & 1 & - \\
\hline $1,2,5$ & & $\begin{array}{l}519-525 \\
525-529\end{array}$ & $\begin{array}{l}524 \\
525 \\
526 \\
527\end{array}$ & $\begin{array}{c}\mathrm{TTG} \rightarrow \mathrm{TGG} / \mathrm{Leu} \rightarrow \text { Pro } \\
\mathrm{ACC} \rightarrow \mathrm{CCC} / \mathrm{Thr} \rightarrow \text { Pro } \\
\mathrm{CAC} \rightarrow \mathrm{CAG} / \mathrm{His} \rightarrow \mathrm{Gln} \\
\text { Del AAG/Lis }\end{array}$ & 1 & 1 & - \\
\hline $3,4,5$ & & $\begin{array}{l}509-514 \\
514-520\end{array}$ & $\begin{array}{l}513 \\
514 \\
515 \\
516\end{array}$ & $\begin{array}{c}\mathrm{CAA} \rightarrow \mathrm{CAC} / \mathrm{Gln} \rightarrow \mathrm{His} \\
\text { Del TTC/Fen } \\
\text { Del ATG/Met } \\
\text { Del GAC/Asp }\end{array}$ & 1 & 1 & - \\
\hline $1,4,5$ & & $\begin{array}{l}514-520 \\
519-525\end{array}$ & $\begin{array}{l}516 \\
522\end{array}$ & $\begin{array}{c}\mathrm{GAC} \rightarrow \mathrm{GAG} / \mathrm{Asp} \rightarrow \mathrm{Glu} \\
\mathrm{TCG} \rightarrow \mathrm{TTG} / \mathrm{Ser} \rightarrow \text { Leu }\end{array}$ & 1 & 1 & - \\
\hline $1,3,4,5$ & Mut D516V & D516V & $\begin{array}{l}516 \\
522\end{array}$ & $\begin{array}{l}\mathrm{GAC} \rightarrow \mathrm{GTC} / \mathrm{Asp} \rightarrow \mathrm{Val} \\
\mathrm{TCG} \rightarrow \mathrm{TTG} / \mathrm{Ser} \rightarrow \text { Leu }\end{array}$ & 1 & 1 & - \\
\hline $1^{a}, 2,3,4,5$ & & rрoB WT & $\begin{array}{l}511 \\
516\end{array}$ & $\begin{array}{c}\mathrm{CTG} \rightarrow \mathrm{CGC} / \mathrm{Leu} \rightarrow \mathrm{Arg} \\
\mathrm{GAC} \rightarrow \mathrm{TAC} / \mathrm{Asp} \rightarrow \mathrm{Tyr}\end{array}$ & 1 & 1 & - \\
\hline $3,4,5$ & & $\begin{array}{l}509-514 \\
514-520\end{array}$ & $\begin{array}{l}514 \\
516\end{array}$ & $\begin{array}{c}\mathrm{TTC} \rightarrow \mathrm{TTT} / \mathrm{Fen} \rightarrow \text { Fen } \\
\mathrm{GAC} \rightarrow \mathrm{GTC} / \mathrm{Asp} \rightarrow \mathrm{Val}\end{array}$ & 1 & 1 & - \\
\hline $1,3,4,5$ & & $514-520$ & $\begin{array}{l}516 \\
518\end{array}$ & $\begin{array}{c}\mathrm{GAC} \rightarrow \mathrm{TAC} / \mathrm{Asp} \rightarrow \mathrm{Tyr} \\
\mathrm{AAC} \rightarrow \mathrm{CAC} / \mathrm{Asn} \rightarrow \mathrm{His}\end{array}$ & 1 & 1 & - \\
\hline $1,3,4,5$ & & $525-529$ & $\begin{array}{l}526 \\
529\end{array}$ & $\begin{array}{c}\mathrm{CAC} \rightarrow \mathrm{CGC} / \mathrm{His} \rightarrow \mathrm{Arg} \\
\mathrm{CGA} \rightarrow \mathrm{CAA} / \\
\mathrm{Arg} \rightarrow \mathrm{Gln}\end{array}$ & 1 & 1 & - \\
\hline $1,3,4,5$ & & $514-520$ & $\begin{array}{l}516 \\
529\end{array}$ & $\begin{array}{c}\mathrm{GAC} \rightarrow \mathrm{GGC} / \mathrm{Asp} \rightarrow \text { Gly } \\
\mathrm{CGA} \rightarrow \mathrm{CAA} / \\
\mathrm{Arg} \rightarrow \mathrm{Gln}\end{array}$ & 1 & 1 & - \\
\hline $1,3,4,5$ & & $514-520$ & $\begin{array}{l}517 \\
518\end{array}$ & $\begin{array}{l}\text { Del CAG/Gln } \\
\text { Del AAC/Asn }\end{array}$ & 1 & 1 & - \\
\hline $1,2,3,4,5$ & & rpoB WT & No mutation & No mutation & 103 & 1 & 102 \\
\hline
\end{tabular}

$a$ : weak hybridization signal; R: resistant; RIF: rifampin; S: sensitive; WT: wild type. 
TABLE II

Oligonucleotides used to prepare the colorimetric reverse dot blot hybridization

\begin{tabular}{|c|c|c|c|c|c|c|c|}
\hline Oligo & $\begin{array}{l}\text { Nucleotide sequence } \\
\qquad\left(5^{\prime}-3^{*} *\right)\end{array}$ & $\begin{array}{l}\text { Size } \\
\text { (bp) }\end{array}$ & $\begin{array}{c}\text { Temperature } \\
\left({ }^{\circ} \mathrm{C}\right)\end{array}$ & $\begin{array}{l}\text { GC } \\
(\%)\end{array}$ & Type & $\begin{array}{l}\text { Position } \\
\text { (codon) }\end{array}$ & $\begin{array}{c}\mathrm{pmol} / \mu \mathrm{L} \\
\text { concentration }\end{array}$ \\
\hline Rif1 & CAGCCAGCTGAGCCAATTCAT & 21 & 61.2 & 52.4 & Wild & 512 & 0.019 \\
\hline Rif2 & TTCATG $\underline{\text { GACCAGAACAACCC }}$ & 20 & 56.9 & 50 & Wild & 516 & 5.0 \\
\hline Rif3 & CGCTGTCGGGGTTGACC & 17 & 59.6 & 70.6 & Wild & 522 & 10.0 \\
\hline Rif4 & 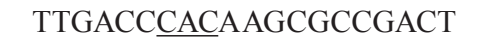 & 20 & 64.8 & 60 & Wild & 526 & 5.0 \\
\hline Rif5 & CTGTCGGCGCTGGGGC & 16 & 63.6 & 81.2 & Wild & 531 & 5.0 \\
\hline Rif2m & CCAATTCATGGTCCAGAA & 21 & 57 & 42.9 & Mutant & 516 & 5.0 \\
\hline Rif4ma & GTTGACCTACAAGCGCCG & 18 & 56.5 & 55.6 & Mutant & 526 & 5.0 \\
\hline Rif4mb & 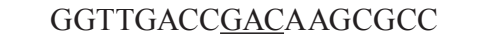 & 18 & 61.2 & 66.7 & Mutant & 526 & 10.0 \\
\hline Rif5ma & CTGTTGGCGCTGGGGC & 16 & 60.9 & 75 & Mutant & 531 & 5.0 \\
\hline Rif5mb & CGACTGTGGGCGCTGG & 16 & 59.5 & 75 & Mutant & 531 & 10.0 \\
\hline IS & AMN-GCCCGTCCCGCCGATCTC & 18 & 67 & 77.8 & Wild & - & 1.16 \\
\hline
\end{tabular}

branes were incubated in TSB buffer, containing $0.33 \mu \mathrm{g} / \mathrm{mL}$ streptavidin-alkaline phosphatase conjugate, for $15 \mathrm{~min}$ at RT. The unbound conjugate was removed by washing in TSB buffer for $10 \mathrm{~min}$, followed by alkaline phosphatase buffer (AP buffer) (100 mM Tris- $\mathrm{HCl}$, $150 \mathrm{mM} \mathrm{NaCl}$ and $5 \mathrm{mM} \mathrm{MgCl2.6H2O,pH} \mathrm{9.5)} \mathrm{for} 10$ min at RT. The hybridized DNA was visualized by adding $40 \mu \mathrm{g} / \mathrm{mL}$ 5-bromo-4-chloro-3-indoyl phosphate and $82.5 \mu \mathrm{g} / \mathrm{mL}$ nitro blue tetrazolium (BCIP/NBT, Sigma) in AP buffer and incubated for $10 \mathrm{~min}$ at RT. A purple precipitate was obtained when there was a perfect match between the probe and the biotinylated PCR product. The colorimetric reaction was blocked with distilled water, the membranes were then dried at RT and the results were recorded. The whole procedure was also performed for the positive and negative controls.

Determination of sensitivity and specificity of the $C R D H$ - The analytical sensitivity of the CRDH was determined by the procedure described above with a serial 10-fold dilution of the M. tuberculosis H37Rv DNA (100 ng-1 pg). To determine the specificity of the CRDH, $100 \mathrm{ng}$ of genomic DNA from each of the following strains was submitted to the entire procedure: Neisseria meningitidis, Streptococcus pneumoniae, Salmonella enterica, Haemophilus influenzae, Escherichia coli (obtained from IPB/LACEN-RS), Mycobacterium marinum, Mycobacterium intracellulare, Mycobacterium scrofulaceum, Mycobacterium gordonae, Mycobacterium avium, Mycobacterium smegmatis, Mycobacterium kansasii, Mycobacterium xenopi, Mycobacterium fortuitum-peregrinum and Mycobacterium phlei (obtained from Fiocruz, Brazil).

\section{RESULTS}

Comparision of CDRH with the proportion method - Five WT probes Rif1, Rif2, Rif3, Rif4 and Rif5 were used to detect the hot-spot region of the rpoB in the $M$. tuberculosis, including the sequence from codon 509-534. The isolates that showed positive signals only with WT probes were interpreted as being sensitive to RIF (Figure).

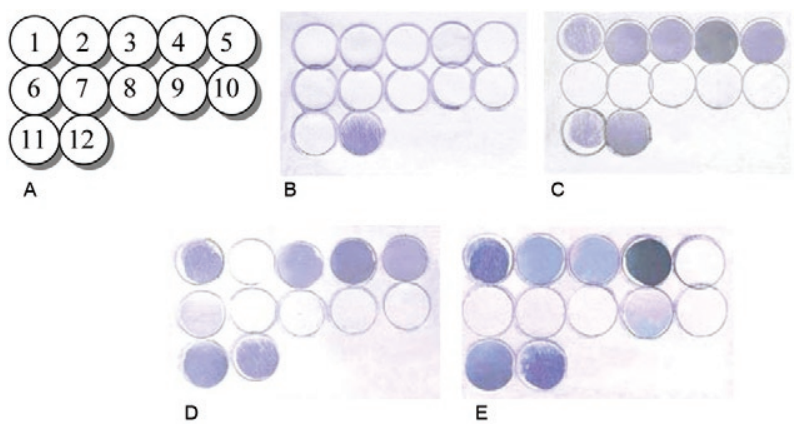

Membrane design and typical results for hybridization patterns with the colorimetric reverse dot blot hybridization. A: the positions of the oligonucleotide probes on the membrane (1: Rif1; 2: Rif2; 3: Rif3; 4: Rif4; 5: Rif5; 6: Rif2m; 7: Rif4ma; 8: Rif4mb; 9: Rif5ma; 10: Rif5$\mathrm{mb}$;1: IS; 12: conjugate control); B: negative control; C: hybridization pattern of the polymerase chain reaction (PCR) products from samples without any mutations at hot-spot region of rpoB gene; $\mathrm{D}$ : hybridization of the PCR products from samples with a mutation at codon $516(\mathrm{GAC} \rightarrow \mathrm{GTC})$; E: hybridization of the PCR products from samples with a mutation at codon 531 (TCG $\rightarrow$ TTG).

The results for a mutant genotype demonstrated the lack of hybridization on one of the five WT probes and/or hybridization on one or more of the mutant probes (Rif $2 \mathrm{~m}$, Rif4ma Rif4mb, Rif5ma or Rif5mb) as shown in Table II.

According to the AST, 52 resistant strains were detected. Out of these strains, four strains were not detected correctly by the CRDH. The first strain had mutations at codons $511(\mathrm{GTC} \rightarrow \mathrm{CGC})$ and $516(\mathrm{GAC} \rightarrow \mathrm{TAC})$ with a weak hybridization signal at the Rif1 and Rif2 respectively. The second strain had a mutation at 516 (GAC $\rightarrow$ TAC) with a weak signal at the Rif2. The third strain had a mutation at $513(\mathrm{CAA} \rightarrow \mathrm{CCA})$ with a weak signal at the Rif1. All three strains were confirmed by sequencing. Finally, the fourth isolate hybridized with all WT probes. The results from the AST showed that 102 (98.1\%) out of 104 M. tuberculosis strains were RIF-sensitive and hybrid- 
ized only with the WT probes. Of the remaining two, one had a mutation at codon $531(\mathrm{TCG} \rightarrow \mathrm{TGG})$ and another had a mutation at the Rif4 region. When compared with the conventional AST, the sensitivity and specificity of the CRDH were $92.3 \%$ and $98.1 \%$, respectively.

Comparision of CRDH with DNA sequencing - Out of $53 \mathrm{M}$. tuberculosis strains that had mutations in the hot-spot region of the rpoB gene according to sequencing, $48(90.6 \%)$ were correctly detected by the CRDH. The first M. tuberculosis strain that was not correctly detected by the CRDH had a mutation at codon 513 $(\mathrm{CAA} \rightarrow \mathrm{CCA})$ and hybridized with all five WT probes, but the hybridization signal was weak at the site of the Rif1 probe. The second strain had a mutation at codon $516(\mathrm{GAC} \rightarrow \mathrm{TAC})$ and hybridized with all five WT probes, but the hybridization signal was weak at the site of the Rif 2 probe. The third strain had point mutations at codons $511(\mathrm{CTG} \rightarrow \mathrm{CGC})$ and $516(\mathrm{GAC} \rightarrow \mathrm{GTC})$ and hybridized with all five WT probes, but the hybridization signal was weak at the site of the Rif1 and Rif2 probes, respectively. The fourth strain had point mutations at codons $516(\mathrm{GAC} \rightarrow \mathrm{GGC})$ and $529(\mathrm{CGA} \rightarrow \mathrm{CAA})$; the mutation at codon 516 was correctly detected by the lack of hybridization at the Rif2, but the mutation at 529 was not detected because of the presence of a hybridization signal at the Rif5. In the fifth strain with point mutations at codons $516(\mathrm{GAC} \rightarrow \mathrm{GTC})$ and $522(\mathrm{TCG} \rightarrow \mathrm{TTG})$, the assay correctly detected the mutation at codon 516 with no hybridization at the Rif2; however, the mutation at codon 522 was not detected due to the presence of a hybridization signal at the Rif3. All 103 strains without a mutation in the hot-spot region of the rpoB were hybridized correctly with all of the WT probes. The site of the mutation probes appeared clear while the spot of IS and $\mathrm{CC}$ were visualized as purple precipitates (C in Figure). The negative control PCR only bound to the spot of CC (B in Figure). When compared with the sequencing, the sensitivity and specificity of the CRDH were $90.6 \%$ and $100 \%$, respectively.
Analytical sensitivity and specificity of the $C R D H$ - The sensitivity for rpoB and IS6110 sequences by PCR was $10 \mathrm{pg}$ in agarose gel. The same amplicons were tested in the CRDH and the sensibility found was $1 \mathrm{pg}$ (data not shown). The PCR products from the following strains did not hybridize with the probes: $N$. meningitidis, S. pneumoniae, S. enterica, H. influenzae, E. coli, M. marinum, M. intracellulare, $M$. scrofulaceum, M. gordonae, M. avium, M. smegmatis, M. kansasii, M. xenopi, M. fortuitum-peregrinum and M. phlei.

GenoType MTBDR assay - The GenoType MTBDR results of 15 strains were compared with the CRDH. The same results were obtained by both the assays. Fourteen samples but one agreed with the sequencing results and had a correct detection of the 516 mutation, but the one strain, with point mutations at codons 516 and 529, only had a correct detection of the 516 mutation.

Clinical isolates - The results of the CRDH for clinical isolates and the comparison with the AST and sequencing are shown in Table III. The CRDH was $100 \%$ concordant with the AST and sequencing.

\section{DISCUSSION}

The early identification of drug resistance would not only help to optimize the treatment of MDR-TB but also break the chains of transmission (Suresh et al. 2007).

The CRDH assay can rapidly detect the presence of point mutations within the 81-bp of the rpoB gene and can identify the organism as a member of the MTBC. The test can successfully detect the five most common mutations of the $r p o \mathrm{~B}$ gene. However, for isolates with other mutations, the CRDH indicates the presence of genetic alteration. The assay showed high analytical sensitivity and specificity. This technique had already been proved very promising in previous study in which the katG315 mutation was successfully characterized in $100 \%$ samples compared to the DNA sequencing (Verza et al. 2009).

Recently, a novel automated molecular test, Xpert MTB/RIF, used a hemi-nested real-time reaction PCR assay to amplify M. tuberculosis specific sequence of

TABLE III

Colorimetric reverse dot blot hybridization $(\mathrm{CRDH})$ results for clinical samples

\begin{tabular}{lcccccc}
\hline & & & \multicolumn{2}{c}{ Sequencing data } \\
\cline { 5 - 6 } $\begin{array}{l}\text { Clinical sample } \\
(\mathrm{n}=30)\end{array}$ & AFB & Culture & AST & $\begin{array}{c}\text { Affected codon(s) } \\
\text { in } r \text { poB gene }\end{array}$ & $\begin{array}{c}\text { Nucleotide/amino acid } \\
\text { change(s) }\end{array}$ & $\begin{array}{c}\text { CRDH } \\
\text { hibridization pattern }\end{array}$ \\
\hline 18 & Neg & Neg & ND & ND & ND & Not hyb \\
2 & Neg & $1 \mathrm{col}$ & ND & ND & ND & Not hyb \\
7 & ++ & +++ & RIF(S) & No mutation & No mutation & Rif1, Rif2, Rif3, Rif4, Rif5 \\
1 & +++ & +++ & RIF(R) & 531 & TCG $\rightarrow$ TTG/Ser $\rightarrow$ Leu & Rif1, Rif2, Rif3, Rif4, Rif5ma \\
CAC $\rightarrow$ GAC/His $\rightarrow$ Asp & Rif1, Rif2, Rif3, Rif4, Rif4mb \\
\hline
\end{tabular}

AFB: acid-fast bacilli; AST: antimicrobial susceptibility testing; col: colony; ND: not done; Neg: negative; Not hyb: not hybridized; RIF(R): rifampin-resistant Mycobacterium tuberculosis; RIF(S): rifampin-sensitive M. tuberculosis; +: 10-99 AFB per 100 fields; ++: 1-10 AFB per field in 50 fields; +++: more than 10 AFB per field in 20 fields. 
the rpoB gene (Boehme et al. 2010, Helb et al. 2010). According to Boehme et al. (2010), the MTB/RIF test was specific in $99.2 \%$ patients without TB. Among culturepositive patients, the Xpert MTB/RIF test identified $98.2 \%$ patients with smear-positive TB and $72.5 \%$ with smear-negative TB. Other studies have also developed approaches which combine an initial real-time PCR with internal inhibition assessment and a pyrosequencing assay to detect the RIF resistance (Halse et al. 2010). The INNO-LiPA Rif.TB and Genotype MTBDR use reverse hybridization approach similar to our $\mathrm{CRDH}$ assay. The INNO-LiPA Rif.TB can detect resistance to the RIF (Morgan et al. 2005), while the GenoType MTBDR assay is able to detect resistance to both INH and RIF simultaneously (Albert et al. 2010, Anek-Vorapong et al. 2010). Although these tests have presented high sensitivity and specificity, their applications are very limited in the developing countries because the commercial kits are very expensive.

The CRDH assay correctly identified $92.3 \%$ RIFresistant strains when compared with the AST. Only one isolate, which was RIF-resistant by the AST, was considered a WT with the CRDH. This result implies that the CRDH method has limitations in specific situations. Some mutations are outside the detection range or in some cases no mutation exists in the hot-spot region of the rpo $\mathrm{B}$ gene even though the isolate is resistant to the RIF. In this case, other resistance mechanisms, such as a permeability barrier or drug efflux pumps probably exist (Bártfai et al. 2001, Heep et al. 2001, Caws et al. 2006).

When compared with the DNA sequencing, the assay correctly identified 90.6\% RIF-resistant strains. In detail, one isolate with the $529(\mathrm{CGA} \rightarrow \mathrm{CAA})$ mutation showed weak hybridization signal at the Rif4 and a strong one at the Rif5. This result was not entirely unexpected because codon 529 is located close to the 3' end of the Rif4 probe and 5' initial of the Rif5 probe. However, this mutation is probably not clinically relevant as it was detected in a strain harbouring the more frequent 516 mutation $(\mathrm{GAC} \rightarrow \mathrm{GGC})$. Another isolate with a mutation at codon $513(\mathrm{CAA} \rightarrow \mathrm{CCA})$ showed a weak hybridization signal at the Rif1, probably due to the high GC content at the opposite end of this probe. We postulate that the other three strains may have had a nonspecific hybridization signal because of mixtures of $M$. tuberculosis strains. The sequencing results for these isolates did not indicate a mixed population. However, another study that compared two commercially available DNA line probe assay observed that the strip tests are better at detecting mixed bacterial populations than the sequencing (Mäkinen et al. 2006). The problem encountered in the identification of the 529 (CGA $\rightarrow$ CAA) mutation by the Genotype MTBDR was probably similar to our results, as described above. The main limitation of the CRDH assay is some weak signals that led to false susceptible results. Other probes and hybridization conditions need to be tested to overcome this limitation.

The CRDH could also detect the rpoB mutation of $M$. tuberculosis in the clinical specimens. The results were concordant when compared with the AST and sequencing. However, the limitation of our study was a smaller number of positive clinical samples (10 out of 30) and only three had mutations. Therefore, a large number of samples should be analyzed for further conclusions.

Comparing the results with the sequencing, the sensitivity and specificity of the CRDH were $90.6 \%$ and $100 \%$, respectively. Therefore, the CRDH test is a promising tool for the early and rapid routine detection of frequent $M$. tuberculosis RIF-resistant genotypes in the mycobacterial laboratory. The CRDH could also be used for the molecular epidemiological studies to monitor the spread of a cluster of drug resistant strains within a community or institution.

The genotypic test has several advantages over classical and other molecular detection methods. With this genotypic test RIF-resistance in M. tuberculosis isolates can be predicted within a day. Compared with the PCRbased sequencing and DNA microarray technique, our method can be performed without expensive devices, whereas the current commercial kits are of limited use in the laboratories of developing countries. However, the molecular drug susceptibility testing results must always be confirmed by phenotypic methods (Miotto et al. 2006, Hillemann et al. 2007).

\section{REFERENCES}

Albert H, Bwanga F, Mukkada S, Nyesiga B, Ademun JP, Lukyamuzi G, Haile M, Hoffner S, Joloba M, O'Brien R 2010. Rapid screening of MDR-TB using molecular Line Probe Assay is feasible in Uganda. BMC Infect Dis 10: 41.

Anek-Vorapong R, Sinthuwattanawibool C, Podewils LJ, McCarthy K, Ngamlert K, Promsarin B, Varma JK 2010. Validation of the GenoType MTBDRplus assay for detection of MDR-TB in a public health laboratory in Thailand. BMC Infect Dis 10: 123.

Bártfai Z, Somoskövi A, Ködmön C, Szabó N, Puskás E, Kosztolányi L, Faragó E, Mester J, Parsons LM, Salfinger M 2001. Molecular characterization of rifampin-resistant isolates of Mycobacterium tuberculosis from Hungary by DNA sequencing and the line probe assay. J Clin Microbiol 39: 3736-3739.

Boehme CC, Nabeta P, Hillemann D, Nicol MP, Shenai S, Krapp F, Allen J, Tahirli R, Blakemore R, Rustomjee R, Milovic A, Jones M, O’Brien SM, Persing DH, Ruesch-Gerdes S, Gotuzzo E, Rodrigues C, Alland D, Perkins MD 2010. Rapid molecular detection of tuberculosis and rifampin resistance. $N$ Engl J Med 363: 1005-1015.

Boom R, Sol CJ, Salimans MM, Jansen CL, Wertheim-van Dillen PM, van der Noordaa J 1990. Rapid and simple method for purification of nucleic acids. J Clin Microbiol 28: 495-503.

Canetti G, Froman S, Grosset J, Hauduroy P, Langerova M, Mahler HT, Meissner G, Mitchison DA, Sula L 1963. Mycobacteria: laboratory methods for testing drug sensitivity and resistance. Bull World Health Organ 29: 565-578.

Caws M, Duy PM, Tho DQ, Lan NT, Hoa DV, Farrar J 2006. Mutations prevalent among rifampin- and isoniazid-resistant $M y$ cobacterium tuberculosis isolates from a hospital in Vietnam. J Clin Microbiol 44: 2333-2337.

Cole ST, Telenti A 1995. Drug resistance in Mycobacterium tuberculosis. Eur Respir J 20 (Suppl.): 701-713.

Halse TA, Edwards J, Cunningham PL, Wolfgang WJ, Dumas NB, Escuyer VE, Musser KA 2010. Combined real-time PCR and rpoB gene pyrosequencing for rapid identification of Mycobacterium tuberculosis and determination of rifampin resistance directly in clinical specimens. J Clin Microbiol 48: 1182-1188. 
Heep M, Brandstätter B, Rieger U, Lehn N, Richter E, Rüsch-Gerdes S, Niemann S 2001. Frequency of rpoB mutations inside and outside the cluster I region in rifampin-resistant clinical Mycobacterium tuberculosis isolates. J Clin Microbiol 39: 107-110.

Helb D, Jones M, Story E, Boehme C, Wallace E, Ho K, Kop J, Owens MR, Rodgers R, Banada P, Safi H, Blakemore R, Lan NT, Jones-López EC, Levi M, Burday M, Ayakaka I, Mugerwa RD, McMillan B, Winn-Deen E, Christel L, Dailey P, Perkins MD, Persing DH, Alland D 2010. Rapid detection of Mycobacterium tuberculosis and rifampin resistance by use of on-demand, nearpatient technology. J Clin Microbiol 48: 229-237.

Hermans PW, Schuitema AR, Van Soolingen D, Verstynen CP, Bik EM, Thole JE, Kolk AH, van Embden JD 1990. Specific detection of Mycobacterium tuberculosis complex strains by polymerase chain reaction. J Clin Microbiol 28: 1204-1213.

Hillemann D, Rüsch-Gerdes S, Richter E 2007. Evaluation of the GenoType MTBDRplus assay for rifampin and isoniazid susceptibility testing of Mycobacterium tuberculosis strains and clinical specimens. J Clin Microbiol 45: 2635-2640.

Hillemann D, Weizenegger M, Kubica T, Richter E, Niemann S 2005. Use of the GenoType MTBDR assay for rapid detection of rifampin and isoniazid resistance in Mycobacterium tuberculosis complex isolates. J Clin Microbiol 43: 3699-3703.

Kapur V, Li LL, Iordanescu S, Hamrick MR, Wanger A, Kreiswirth BN, Musser JM 1994. Characterization by automated DNA sequencing of mutations in the gene (rpoB) encoding the RNA polymerase beta subunit in rifampin-resistant Mycobacterium tuberculosis strains from New York City and Texas. J Clin Microbiol 32: 1095-1098.

Kent PT, Kubica GP 1985. Public health mycobacteriology. A guide for the level III laboratory, Centers for Diseases Control, Atlanta, 207 pp.

Lawn SD, Wilkinson R 2006. Extensively drug resistant tuberculosis. BMJ 333: 559-560.

Mäkinen J, Marttila HJ, Marjamäki M, Viljanen MK, Soini H 2006. Comparison of two commercially available DNA line probe assays for detection of multidrug-resistant Mycobacterium tuberculosis. J Clin Microbiol 44: 350-352.
Miotto P, Piana F, Penati V, Canducci F, Migliori GB, Cirillo DM 2006. Use of GenoType MTBDR assay for molecular detection of rifampin and isoniazid resistance in Mycobacterium tuberculosis clinical strains isolated in Italy. J Clin Microbiol 44: 2485-2491.

Morgan M, Kalantri S, Flores L, Pai M 2005. A commercial line probe assay for the rapid detection of rifampicin resistance in Mycobacterium tuberculosis: a systematic review and meta-analysis. BMC Infect Dis 5: 62.

Ramaswamy S, Musser JM 1998. Molecular genetic basis of antimicrobial agent resistance in Mycobacterium tuberculosis: 1998 update. Tuber Lung Dis 79: 3-29.

Suresh N, Singh UB, Gupta C, Arora J, Rana T, Samantaray JC 2007. Rapid detection of rifampin-resistant Mycobacterium tuberculosis directly from stained sputum smears using single-tube nested polymerase chain reaction deoxyribonucleic acid sequencing. Diagn Microbiol Infect Dis 58: 217-222.

Telenti A, Honoré N, Bernasconi C, March J, Ortega A, Heym B, Takiff HE, Cole ST 1997. Genotypic assessment of isoniazid and rifampin resistance in Mycobacterium tuberculosis: a blind study at reference laboratory level. J Clin Microbiol 35: 719-723.

Telenti A, Imboden P, Marchesi F, Lowrie D, Cole S, Colston MJ, Matter L, Schopfer K, Bodmer T 1993. Detection of rifampicinresistance mutations in Mycobacterium tuberculosis. Lancet 341: 647-650.

Valim AR, Rossetti ML, Ribeiro MO, Zaha A 2000. Mutations in the rpo B gene of multidrug-resistant Mycobacterium tuberculosis isolates from Brazil. J Clin Microbiol 38: 3119-3122.

van Soolingen D, de Haas PE, Hermans PW, van Embden JD 1994. DNA fingerprinting of Mycobacterium tuberculosis. Methods Enzymol 235: 196-205.

Verza M, Maschmann R de A, Silva MSN, Dalla Costa ER, Ribeiro MO, Rosso F, Suffys PN, Tortoli E, Marcelli F, Zaha A, Rossetti MLR 2009. In house colorimetric reverse hybridisation assay for detection of the mutation most frequently associated with resistance to isoniazid in Mycobacterium tuberculosis. Mem Inst Oswaldo Cruz 104: 710-714.

WHO - World Health Organization 2009. Global tuberculosis control: epidemiology, strategy, financing. Available from: http://www. who.int/tb/publications/global_report/2009/en/index.html. 